\title{
Diskurzivna neenakost in konstrukcija »govorno-jezikovnega primanjkljaja« deprivilegiranih družin in otrok
}

\author{
Lucija Klun, Inštitut za slovensko izseljenstvo in migracije ZRC SAZU
}

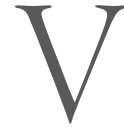

prispevku bomo izhajali iz: I) vztrajajoče povezanosti med družbeno pripadnostjo in razvojnim potekom ter učnim uspehom otrok, 2) podobno vztrajnih poskusov družboslovnih disciplin, da omenjeno povezanost izmerijo, korelirajo in interpretirajo, 3) dejstva, da se številne raziskave v iskanju »nosilca družbene reprodukcije« obrnejo $h$ govoru in jeziku deprivilegiranih staršev in otrok. Pojav zanimanja za povezanost med družbeno-razredno pripadnostjo in govorom/jezikom postavljamo na začetek 20. stoletju - na presek humanistike (predvsem filozofije, jezikoslovja) in psihologije. Takrat se zgodita dva vzporedna »preobrata«: na področju humanistike preobrat fokusa, ki je danes poznan pod besedno zvezo »jezikovni obrat《 (Rorty, 1967). Na področju psihologije pa - pod taktirko humanistov - pomik od biologističnih do sociokulturnih pogledov na razvoj (Olson in Bruner, 1996; Vigotski, 2010). V tem »ujemajočem « družboslovnem momentu, kjer se zanimanja - sociologije, filozofije, psihologije - srečajo na disciplinarnem preseku, vznikne živahna produkcija. Lingvistika napravi skokovit napredek na področju študij leksike, sintakse in slovnice (Halliday, 1978, 1995), lingvistično ozkogledost spodjeda vstop (sociokulturnega, kasneje pa še družbenega, Gumprez in Hymes, 1964; Bourdieu, 1991; Labov, 1972) konteksta, razvojna psihologija pa pokaže na specifične - posredne in neposredne korelacije med značilnostmi primarnega okolja in hitrostjo govorno-jezikovnega razvoja. Ta točka »zgostitve «, katere zagon vztraja v 21. stoletje, je polna meddisciplinarnih razkorakov, apropriacij in trkov.

$\mathrm{V}$ članku bomo pregledali raziskave, pokazali na trende in na menjave »hegemonih« disciplin, ki se vrstijo v času. Predvsem bomo pozorni 
na zadnja tri desetletja, v katerih je razumevanje razmerja »razred - razvoj « vse bolj odvisno od zbrane empirije. Ter na to, kako naraščajoč pozitivizem vpliva na razlagalno moč modelov. Poskusili bomo pokazati, da so lahko izsledki raziskav nedosledni, čeprav so (empirično) točni. Predvsem, kadar odvržejo teoretski okvir, ki je znanstveno pot »utrl«, in konceptualne zasnove zamenjajo za bolj »instante« kategorizacije, ki ustrezajo pridobljeni empiriji.

\section{Raziskave govora in jezika otrok ter družin: disciplinarni koraki in razkoraki}

Da bi sploh mogli iskati odgovore na ta vprašanja in pokazati na »disciplinarne tokove «, bomo kronološko nanizali prelomne raziskave s področja. Psihologinja McCharty (1930) je bila ena prvih, ki je pokazala govorno-jezikovne razlike med otroci različnih družbenih razredov. Ugotovila je, da otroci srednjega razreda glede na otroke delavskega razreda uporabljajo daljše stavke ter le-te bolj kompleksno slogovno in sintaktično urejajo. V I960-ih je naraščalo zanimanje za kulturo podrazreda v Združenih državah (Lawton, 1968), jezikovne »težave« otrok pa so bile vse pogosteje povezane $\mathrm{z}$ vprašanjem udejanjanja meritokracije v šolstvu. Zgodnje Bernsteinove raziskave (1958, 2003a) so na primer pokazale, da je neenaka uspešnost med otroki iz različnih družbenih skupin povezana predvsem z različnimi jezikovnimi dispozicijami. Otrokom iz dveh družbenih skupin (srednji in delavski razred) je dal v reševanje dva testa inteligentnosti - verbalnega (test zahteva daljše odgovore) in neverbalnega (test je sestavljen predvsem iz matematičnih in logičnih nalog). Ugotovil je, da je razkorak v rezultatih med družbenima skupinama močno odvisen od načina preverjanja inteligentnosti. ${ }^{1}$

Tabela r: Prikaz rezultatov merjenja verbalne in neverbalne inteligentnosti (povzeto po Bernstein, 2003a).

\begin{tabular}{lcc} 
& Verbalni test inteligentnosti & Neverbalni test inteligentnosti \\
Nižji delavski razred & 41,9 & 47,4 \\
\hline Srednje razred & 60,2 & $5 \mathrm{I}, 4$ \\
\hline Razlika & 18,3 & 4,04 \\
\hline
\end{tabular}

$\mathrm{Na}$ podlagi raziskovanja je osnoval dve »razredno zaznamovani« obliki jezika, ki naj bi vplivali na to, koliko posameznik obvladuje »diskurz« formalnih institucij: javni jezik in formalni jezik. Za javni

I Obe skupini sta reševali dva testa: Raven's Progressive Matrices test (1938, v Bernstein, 2003a), ki je neverbalni inteligenčni test, in Mill Hill Vocabulary Scale Form I Senior (ibid.), ki je verbalni test inteligentnosti (ibid.). 
jezik, ki naj bi ga govorili predvsem pripadniki nižjih razredov, je izpostavil sledeče značilnosti: kratke povedi, slovnična preprostost, siromašna sintaksa, preprosta raba veznikov, omejena uporaba pridevnikov in prislovov, trditve oblikovana kot implicitna vprašanja. Za formalni jezik, ki naj bi ga uporabljali pripadniki srednjega in višjega družbenega razreda, pa je navedel značilnosti: pravilna slovnica in sintaksa, kompleksne povedi, uporaba propozicij, ki nakazujejo logična razmerja ter opredeljujejo prostor in čas, širok nabor rabe prislovov in pridevnikov, eksplicirani individualni pomeni. Sklenil je, da je raba ene in druge oblike v »funkciji družbene strukture «.

Naslednjo, verjetno najbolj odmevno, raziskavo na področju sta napravila Hart in Risley (1995, 2003). Sama sta se prištevala med raziskovalce, ki so v vojni proti revščini ( $k i$ je od šestdesetih naprej tekla v ZDA) »svoje $z$ nanje prinesli na frontno linijo $v$ optimističnem poskusu zgodnjega interveniranja v razvoj « (2003: str. I). Njuni raziskovalni vzgibi so izhajali iz (neuspešnih) kliničnih programov, ki sta jih s sodelavci izvajala $\mathrm{v}$ siromašnih predelih Kansasa. Poročala sta, da je bilo delo klinike namenjeno pospeševanju razvoja otrok - to naj bi dosegli z učenjem novih besed in osredotočenim pogovorom z otroki. Ugotovili so, da je moč s programom začasno doseči povečan besednjak in »izboljšan razvoj《, nemogoče pa je »spremeniti razvoje trajektorije« (ibid.: str. 2). Zaradi opažene »trdovratnosti« razvojnih potekov sta se raziskovalca obrnila k zgodnjemu jezikovnemu okolju otrok. Dve leti in pol sta spremljala 42 družin; vsako sta opazovala po eno uro na mesec. Z opazovanjem sta pričela, ko so bili otroci stari 7-9 mesecev, zaključila pa, ko so dopolnili tri leta. Njun namen je bil dvojen: opazovati interakcije, ki se dogajajo v družinah majhnih otrok, ter izmeriti dejanski govorno-jezikovni razvoj opazovanih otrok. Vzorec sta pridobila z metodo snežne kepe: pripadnike višjih družbenih razredov sta poiskala med sodelavci Univerze v Kansasu, pripadnike »podrazreda « pa izbrala iz vrtca v revni soseski. I3 vključenih družin je bilo iz višjega družbenega razreda, 23 iz delavskega razred in 6 družin, ki so živele s socialnimi prejemki. V družinah sta posnela vse interakcije, kvantiteto govora, ki je bil namenjen otrokom, pa sta podatkovno obdelala in primerjala po družbenih skupinah.

Tabela 2: Število izrečenih besed v družinah iz različnih družbenih skupin (povzeto po Hart in Risley, 2003)

\begin{tabular}{lcccc} 
& $\begin{array}{c}\text { Število besed/ } \\
\text { ura }\end{array}$ & $\begin{array}{c}\text { Število besed v } \\
\text { tednu (100 ur) }\end{array}$ & $\begin{array}{c}\text { Število besed v } \\
\text { letu (5200 ur) }\end{array}$ & $\begin{array}{c}\text { Število besed v } \\
\text { štirih letih }\end{array}$ \\
$\begin{array}{lcccc}\text { Profesionalna družina } \\
\text { Delavska družina }\end{array}$ & I251 & 215,000 & $1 \mathrm{I}, 2$ milijona & 45 milijonov \\
\hline $\begin{array}{l}\text { Družina s socialno } \\
\text { podporo }\end{array}$ & 616 & 62,0000 & 6,5 milijonov & 26 milijonov \\
\hline
\end{tabular}


Kot je opaziti iz tabele, sta iz omejenega korpusa - povprečno 4 ure posnetih interakcij v 42 družinah - pridobljene podatke zelo vehementno posplošila. Najprej na povprečno število besed, ki jih »sliši « otrok iz različnih družbenih skupin: številka naj bi bila 616 besed na uro za otroka družine s socialno podporo, I25I za otroka iz delavske družine in $2153 \mathrm{za}$ otroka iz družine višjega družbenega razreda. In še naprej: Hart in Risley sta predpostavila, da je mogoče na podlagi pridobljene empirije »oceniti absolutni obseg otrokovih zgodnjih izkušenj« (2003: str. 5) - med okolji najbolj in najmanj privilegiranih otrok zeva po njuni oceni 30 milijonska besedna vrzel.

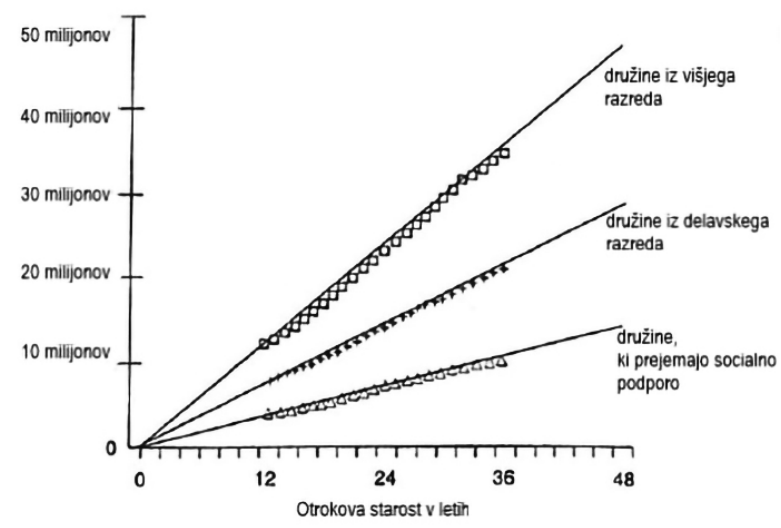

Slika I: Število besed, ki jih skrbniki namenijo otrokom v razlicnih socialnoekonomskib skupinah (Hart in Risley, 2003: str.5).

Obenem sta ob preverjanju otrokovega govornega razvoja pokazala, da graf rasti otrokovega besednjaka $v$ času skoraj povsem sovpada z grafom kumulativnih verbalnih izkušenj.

Spoznanjem sta dodala opozorilo, da je to »zgodnjo katastrofo « nujno preprečiti. Rešitev sta videla v pedagoškem delu, ki bi se moralo »začeti ob rojstvu otroka in trajati vsa zgodnja leta« (2003: str. 6). S takim programom naj bi učinke neugodnega socialno-ekonomskega ozadja zmanjšali s krpanjem ugotovljene leksikalne neenakosti, ta dodatna spodbuda pa naj bi povečala možnost za otrokov izstop iz začaranega kroga revščine:

Več kot starši govorijo z otroki do tretjega leta starosti, večji bodo akademski dosežki otroka v življenju. Tudi deprivilegiranost, ki izhaja iz socialno ekonomskega statusa, je mogoče preseči (Risley, 2006, v Gilkerson in Richards, 2009: str. 2). 


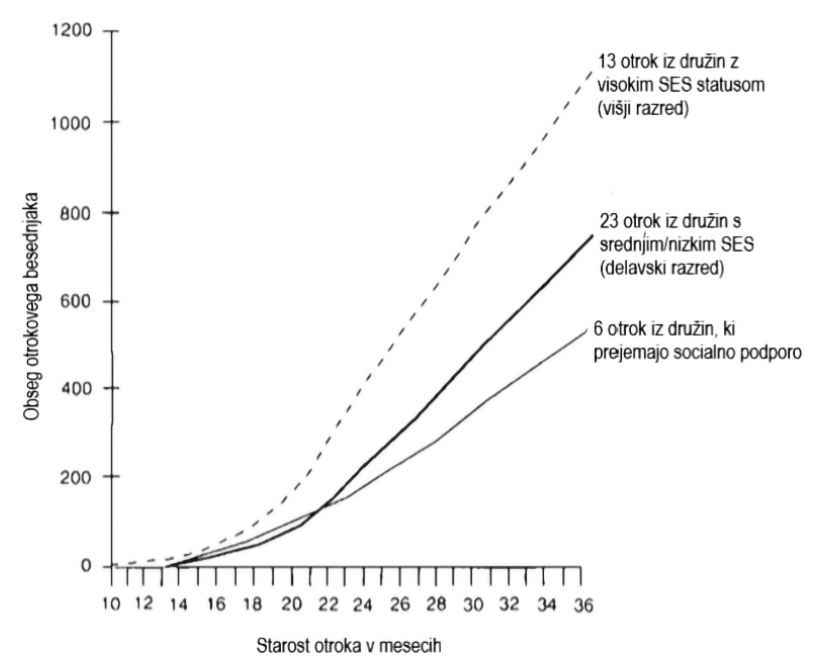

Slika 2: Obseg otrokovega besednjaka glede na starost v razlicnih socialnoekonomskih skupinah (Hart in Risley, 2003: str: 4).

Avtorja sta napravila preboj na področju. Čeprav je njuno delo doletela vrsta metodoloških in vsebinskih kritik, ostaja ena najbolj odmevnih in citiranih raziskav s področja (tudi s strani slovenskih avtorjev, npr. Marjanovič Umek in Fekonja, 2019; Jager, 2015). Poleg tega sta avtorja uvedla »dvosmerni « raziskovalni pristop, ki so se ga kasneje poslužili mnogi drugi. To je sočasno raziskovanje otroka (njegovega razvoja, veščin, kompetenc, znanja) in okolja (značilnosti staršev, navade, vsakdanja komunikacija - kvantiteta in »kvaliteta《). Ker je - sploh raziskovanje družinskega okolja - izredno zamudno in metodološko zahtevno, se je na tem področju v zadnjih desetletjih zgodil hiter tehnološki napredek. Namesto raziskovalcev, ki snemajo, transkribirajo, štejejo izrečene besede in sekvence ter analizirajo in posplošujejo zbrane podatke, danes meritve opravi merilna in analitična programska oprema, ki jo je razvila LENA Research Foundation. ${ }^{2}$ Ta je sestavljena iz snemalnika (ki ga otrok nosi v prirejenem žepu puloverja) in programske opreme, ki pridobljene zvočne posnetke analizira (Ganek in Eriks-Brophy, 2017). Večina snemanj poteka $12 \mathrm{ur}$, iz zbranih podatkov program izlušči število izrečenih besed odraslega (adult word count), število izrečenih glasov/besed otroka (child vocalization count) in število pogovornih obratov (zamenjav v interakciji med otroki in odraslimi skrbniki). Določen napredek pri mapiranju zgodnjega okolja je nastal tudi s prevodom angleških testov za starše - z njimi preverjajo bralno pismenost staršev, njihove prakse (skupno branje, pripovedovanje),

2 Oprema je relevantna za raziskovalce v angleških govornih okoljih. 
njihovo poznavanje značilnosti govornega razvoja otrok in poznavanje literature za otroke (Test Knowledge of Infant Development Inventory, MacPhee, ${ }_{1981}$ in Checklist of Titles and Authors of Children's Books »Lista naslovov in avtorjev otroških knjig«, oboje v Marjanovič, Umek in Fekonja Peklaj, 20II).

Vse našteto je omogočilo povečanje obsežnosti in zanesljivosti podatkov o otrokovem okolju. Večjo zanesljivost, objektivnost in natančnost podatkov o govoru otroka pa so omogočili standardizirani testi; raziskovalci, tudi v Sloveniji, največkrat uporabijo: lestvico govornega razvoja (RDLS III - Reynell Developmental Language Scale, Edwards et al., 1997 - v slovenski različici »Lestvica govornega razvoja $\ll,{ }^{3}$ Fekonja, Marjanovič Umek, Kranjc, 2005) ter MacArthur Bates Communicative Development Inventories (Fenson et al., 2006, v Fernald, Marchman in Weisleder, 20I3 ) - v slovenski različici »Lista razvoja sporazumevalnih zmožnosti (LRSZ) « ${ }^{4}$ (Marjanovič Umek et al., 20II). Najpomembnejši učinek novih instrumentov in analitičnih orodij je večanje vzorcev in števila pridobljenih podatkov. Če so bile zgodnje raziskave (Bernstein, 2003a; Dawe, 1942; Hart in Risely, 1995; Lawton, 1968; McChraty, 1930 in 1946) opravljene na vzorcih nekaj deset otrok in družin, so sedaj te številke mnogo večje - na primer v raziskavi Letts et al. (2013) je bilo udeleženih I226 otrok, v raziskavi Marjanovič Umek in Fekonje (2019) pa 536 malčkov. Podoben trend velja za številčnost pridobljenih podatkov. Gilkerson in Richards (2009) sta na primer v raziskavi s sistemom LENA zbrala 32.000 ur zvočnih posnetkov. Pokazali bomo rezultate nekaterih raziskav iz tega $\gg$ novega vala «.

Gilkerson in Richards (ibid.) sta družine razdelila v deset družbenih skupin, glede na dohodkovni precentil. Jezikovno okolje sta merila I2 ur na dan, opravila sta 2.682 snemanj (med starostjo 2 meseca in 48 mesecev) ter ugotovila, da je dohodek družine močno povezan z vsemi tremi merjenimi spremenljivkami.

Rezultati so torej podobni kot pri Hart in Risley (2003): z višanjem dohodka se veča gostobesednost $\mathrm{v}$ gospodinjstvu. Raziskovalca sta preverila tudi povezanost med številom izrečenih besed odraslega in otrokovim rezultatom na preverjanju govora in sporazumevanja (PLS - Preschool Language Scale). Podatki so v grafu spodaj.

3 Primeren za preverjanje govornega razumevanja in govornega izražanja otrok.

4 Pripomoček je primeren za raziskovanje govora malčkov (del testa za malčke 8-16 mesecev, drugi del za malčke I6-30 mesecev). 
Tabela 3: Prikaz rezultatov raziskave z uporabo sistema LENA: število izrečenih besed odraslega, pogovorni obrati, število vokalizacij otroka glede na ekonomski status družine. Vrednosti, ki jih prikazuje tabela, so reprezentativne za malčke, stare 24 mesecev (Gilkerson in Richards, 2009: str. IO).

\begin{tabular}{cccc}
$\begin{array}{c}\text { Dohodkovni } \\
\text { percentil }\end{array}$ & $\begin{array}{c}\text { Število izrečenih } \\
\text { besed odraslega }\end{array}$ & Pogovorni obrati & $\begin{array}{c}\text { Število otrokovih } \\
\text { vokalizacij }\end{array}$ \\
\hline 99 & 29.428 & I.163 & 4.406 \\
\hline 90 & 20.824 & 816 & 3.184 \\
\hline 80 & 17.645 & 688 & 2.728 \\
\hline 70 & 15.516 & 603 & 2.422 \\
\hline 60 & 13.805 & 535 & 2.174 \\
\hline 50 & 12.297 & 474 & 1.955 \\
\hline 40 & 10.875 & 428 & 1.747 \\
\hline 30 & 9.451 & 361 & 1.338 \\
\hline 20 & 7.911 & 300 & 1.024 \\
\hline 10 & 6.003 & 225 & \\
\hline
\end{tabular}

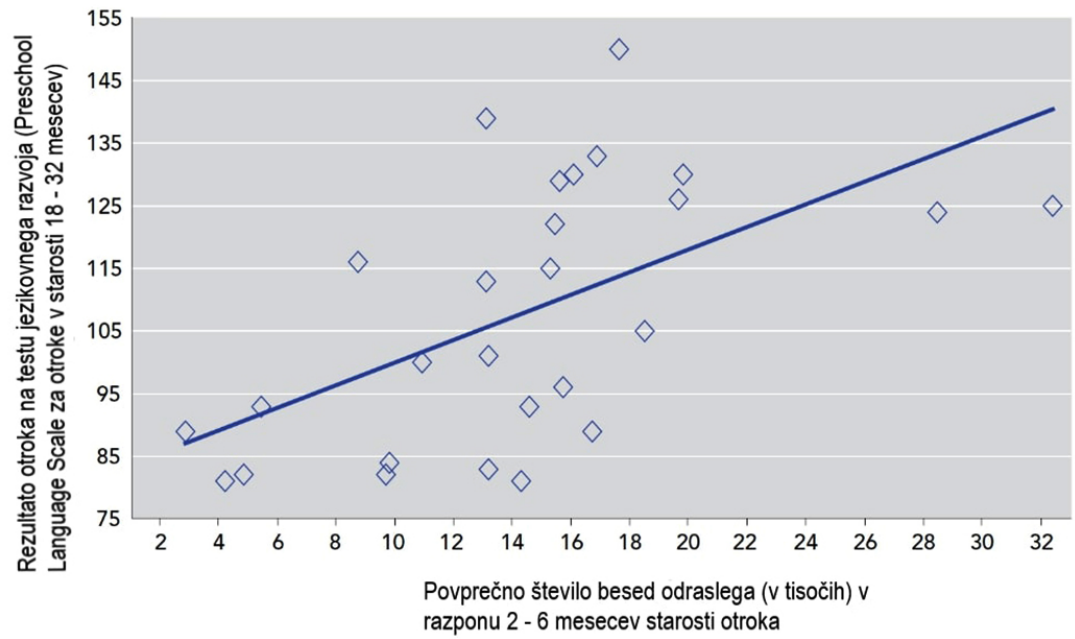

Slika 3: Povezanost med jezikounim okoljem (stevilo izrečenih besed skrbnika) in otrokovo uspeśnostjo na testu jezikounega razvoja (Gilkerson, Richards, 2009).

Naslednja raziskava Gilkersona in sodelavcev (2017) je prav tako nastala s podporo programske opreme LENA. Vključili so 329 otrok, jezikovno okolje so snemali 46 mesecev (med starostjo 2 in 48 mesecev), pri čemer so bili osredotočeni na povezanost med stopnjo materine izobrazbe 


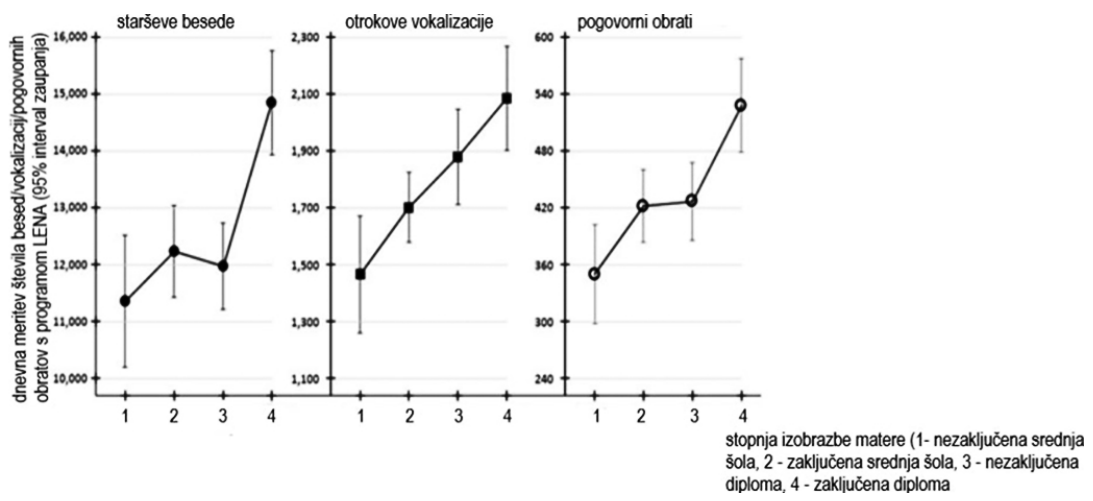

Slika 4: Vpliv izobrazbe matere na jezikouno okolje drużin (stevilo besed, ki jih mati nameni otroku, stevilo otrokovih besed in stevilo jezikounih obratov) (Gilkerson et al., 2017).

(primerjava 4 skupin ${ }^{5}$ ) in številom I) besed odraslih, 2) vokalizacij otrok ter 3) pogovornih obratov.

Rezultati so pokazali, da otroci izobraženih mater producirajo 42 odstotkov več vokalizacij, v tem okolju pa je prisotnih tudi 50 odstotkov več pogovornih obratov.

\section{Slovenske raziskave}

V slovenskem prostoru je skupina sodelavcev s področja razvojne psihologije napravila nekaj pomembnih raziskav na področju. Posebno prodoren uvid o dejavnikih, ki posredujejo med izobrazbo staršev in govorno-jezikovnim razvojem malčkov, je prinesla raziskava Marjanovič Umek in Fekonje (2019). Avtorici sta preučevali varovalne dejavnike in dejavnike tveganja družinskega okolja v povezavi z zgodnjim razvojem dojenčkov in malčkov. Osredotočili sta se na učinek izobrazbe staršev in pogostosti skupnega branja na besednjak in sintakso malčkov. Ugotovili sta, da je obseg besednjaka 3-mesečnih malčkov pomembno napovedovala pogostost skupnega branja, katerega pomemben napovednik pa je bila izobrazba staršev. Analiza je pokazala majhen, a statistično pomemben učinek izobrazbe staršev na besednjak, slovnično zapletenost stavkov in povprečno dolžino stavkov pri 3 I mesecih. Učinek izobrazbe staršev je pri tem posredovan preko pogostosti skupnega branja: ta predstavlja mediacijsko spremenljivko med izobrazbo staršev in govorom malčkov. 


\section{Nevroznanost}

Romeo in sodelavci (2018a, 2018b) so preučili povezanost med okoljem otroka in razvojem možganov. Izhajali so iz raziskav, ki so pokazale, da je mogoče razliko $v$ socialno-ekonomskem statusu povezati z razliko v razvoju možganov otrok - na primer z volumnom sive možganovine (Rizada et al., 2008, v 2018b), z makrostrukturo (Luby et al., 2013; Rizada et al., 2008, ibid.) in z mikrostrukturo (Gianaros et al., 2013; Urssache in Noble, 2016, ibid.) bele možganovine. Postavili so tezo (Romeo et al., 2018a, ibid.), da se te razlike pojavljajo zaradi nekaterih »neposrednih dejavnikov okolja $v$ zgodnjem otroštvu«. Nanašali so se na spoznanja predhodnikov (Hart in Risely, 1995), da otroci iz družin z nizkim SES slišijo manj besed ter da kvantiteta jezika, ki so mu »izpostavljeni«, napoveduje njihove kasnejše kognitivne zmožnosti (glej tudi Hirsh-Pasek et al., 2015; Rowe, 2012).

Romeo in soavtorji (Romeo et al., 20I8b) so preverili povezanost med značilnostmi otrokovega okolja in asociacijskimi povezavami možganovine $\mathrm{v}$ Brocovem področju levega inferiornega dela frontalnega režnja. Okolje so izmerili s programom LENA (število besed odraslega, vokalizacij otroka in pogovornih obratov) ter ga obenem definirali s socialno-ekonomskim statusom (»določili so ga glede na dohodkovno situacijo družine, izobraževalni kapital in relativni socialni status $\ll^{6}-6$ dohodkovnih skupin, 5 skupin glede na stopnjo izobrazbe). Slike možganov so pridobili s tremi magnetnoresonančnimi slikanji. Pri otrocih so preverili tudi verbalne in neverbalne kognitivne sposobnosti (z Wechsler Preschool and Primary Scale of Intelligence (Wechsler, 2012, ibid.) in Peabody Vocabulary Test (Dunn in Dunn, 2007, ibid.) ter Core Language Score of the Clinical Evaluation of Language Fundamentals, sth edition (Wiig et al., 2013, ibid.)).

Ugotovili so (ibid.), da je SES v korelaciji z izmerjeno »bogatostjo« jezikovnega okolja, prav tako pa $\mathrm{z}$ rezultati na verbalnih in $\mathrm{v}$ manjši meri na neverbalnih testih kognicije. SES je bil v rezultatih sicer povezan $z$ rezultati otroka na testih kognicije, vendar so avtorji poudarili, da je $-k a-$ dar je SES kontroliran - le število »pogovornih obratov《v primarnem okolju tisto, ki korelira zotrokovimi verbalnimi zmožnostmi. Na podlagi tega so sklenili: razlike $\mathrm{v}$ domači komunikaciji delujejo na otrokove verbalne zmožnosti ${ }^{7}$ - onkraj socialno ekonomskih determinant. Prav tako so

6 Starši so izpolnili vprašalnik o letnem dohodku, najvišji stopnji pridobljene izobrazbe staršev (o - manj kot srednja šola, I - srednja šola, 2 - višja šola, 3 - visoka šola/fakultetna diploma, 4-magisterij ali doktorat).

7 Rezultati na neverbalnih testih kognitivne zmožnosti niso bili pomembno povezani z značilnostmi okolja. 
pokazali, ${ }^{8}$ da ob kontroliranem SES število pogovornih obratov pozitivno korelira $s$ frakcijsko aziotropijo" (FA) in negativno $\mathrm{z}$ radialno difuzivnostjo $^{10}$ (RD). ${ }^{11} \mathrm{~S}$ tem so pokazali na specifićno pomembnost pogovornih obratov, ki vplivajo na razvoj določenih delov otrokovih možganov ne glede na socialnoekonomski status (izobrazbo in dohodke staršev). Avtorji so zaključili, da ima raziskava veliko vrednost za praktično delo. Zdelo se je, da bi bilo mogoče »vpliv« socialno-ekonomskih dejavnikov »preiti«, če bi starši z otroci veliko in pravilno komunicirali:

To nakazuje, da ni dovolj, da zgodnji interventni programi spodbujajo starše, naj govorijo z otrokom, ampak da jih spodbujajo, naj govorijo z otrokom zato, da omogočijo optimalni razvoj njegovih možganov (Romeo et al., 20I8b: str. 7876).

\section{Več podatkov, manj analitične moči}

Iz prejšnjega razdelka je mogoče razbrati, da smo v zadnjih desetletjih priča »kvantitizaciji« razlag razmerja med družbeno-razredno pripadnostjo in (govorno-jezikovnim) razvojem otrok. To je opaziti v večanju števila raziskav, števila udeležencev $\mathrm{v}$ njih, količini pridobljenih podatkov, v novejši programski opremi, ki omogoča avtomatizirano analizo podatkov, pa tudi v razmahu disciplin, ki se s področjem ukvarjajo. Sprva so v polju oscilirale psihologija, lingvistika, zatem sociologija in bolj specifično sociolingvistika, v zadnjih desetletjih pa intenzivneje razvojna psihologija, nevroznanost, logopedija.

Uporabljeni instrumenti so standardizirani, zaradi česar so raziskave bolj zanesljive in objektivne. Nova programska oprema omogoča strm porast zbranih in analiziranih podatkov. A zdi se, da podatkovna moč raziskav sicer narašča, vendar sočasno upada analitična moč (Klun, 2019).

Raziskovalci uporabljajo difuzijsko magnetnoresonančno slikanje, katerim preverjajo delovanje asociacijskih povezav vlaken bele možganovine. Na osnovi difuzijskega magnetnoresonančnega slikanja je mogoče sklepati o usmerjenosti živčnih vlaken preko termičnega preučevanja gibanja molekul vode.

Frakcijska anziotropija ocenjuje razmerje med prevladujočo usmerjenostjo difuzije in velikostjo celokupne difuzije. Velja, da se s staranjem in pri nevrodegenerativnih obolenjih zaradi celičnih okvar zmanjša usmerjenost difuzije in poveča celokupna difuzija, kar se odraža v zmanjšani $F A$.

II V kombinaciji ta rezultata nakazujeta, da se večje število pogovornih obratov povezuje z večjo koherentnostjo difuzije, kar bi lahko bil kazalec večje aksonalne mielizacije (Lebel et al., 2017, ibid.). Številno pogovornih obratov med odraslim in otrokom se torej- neodvisno od SES - povezuje z močjo koherence med dorzalnima svežnjema bele možganovine. Ta lokalizacija potrjuje spoznanja drugih raziskav (Sheridan et al., 2or2, ibid.), da izpostavljenost jeziku vpliva predvsem na levo frontalno kortikalno področje. 
Kategorije, kot so »razred «, »družbena skupina«, »socialno-ekonomska skupina«, so konceptualno krhke in predstavljajo zgolj (izračunljivo) spremenljivko, s katero je moč korelirati podatke o razvoju otrok. Neenakost postane vrsta $\gg$ individualiziranih in partikularnih odmikov« (Mladenović, 2016: str. 96), predvsem v obliki opisov primarnega okolja otrok, pri čemer se višjerazredna okolja enači s kakovostjo in razvojno stimulativnostjo, nižjerazredna okolja pa se ima za nespodbudna; zapisi nekaterih avtorjev pustijo vtis, da deprivilegirani starši (s svojimi vprašljivimi vzgojnimi in komunikacijskimi načini) razvoj otrok celo »zavirajo $\ll$. V iskanju »krivca « za socialno reprodukcijo se avtorji obrnejo $\mathrm{k}$ intimnemu družinskemu okolju revnih družin in odgovornost za vztrajajočo neenakosti naložijo na »pleča posameznikov in posameznic « (ibid.: str. 96), predvsem pa mater. ${ }^{12}$ Kompleksne strukturne neenakosti členijo na ravni partikularne pojavnosti in neenakost upodobijo (zgolj) kot različnost $\mathrm{v} v$ sakdanjih praksah privilegiranih in deprivilegiranih družin. Raziskovalci se prizadevno osredotočijo na iskanje posrednika med $\gg$ razredom $\ll$ in $\gg$ razvojem $\ll$, pri čemer suspendirajo vrsto drugih (že opravljenih) uvidov v dinamiko strukturnih neenakosti, ki vplivajo na diskurzivne (z)možnosti ljudi (Atkinson, 1985). Tako pri svojem »zasledovanju « posrednih in neposrednih vplivov (zgodnjega okolja na razvoj otroka) idejo »družbene skupine « konceptualno razkosajo in poenostavijo na vrsto empirično opredeljivih mikropraks družin. Zdi se, da so te razlike celo plod izbire staršev: čeprav imajo družine nizke dohodke, bi lahko starši otrokom vseeno brali in z njimi več govorili. Pri tem zanemarijo zgodovinski, kulturni, politični, ekonomski, socialni in jezikovni kontekst, $\mathrm{v}$ katerega so vpeti raziskovani otroci in starši, njihov govor, njihova »družbena pripadnost«, interakcije, vzgojne prakse ... Iz konteksta izluščijo zgolj izolirane podatke, ki jih v pozitivistični maniri med seboj korelirajo. A ta redukcionistična narava »novih raziskovalnih pristopov« ima nekatere pomembne učinke:

I) Nejasnost v pojmu »družbene skupine « in »družbene neenakosti«;

2) Nejasnost mediacije (Kaj posreduje med družbeno strukturo in razvojem otroka?);

3) Prenagla indukcija in posploševanje rezultatov ter enačenje korelacije s kavzalnostjo;

4) Izmerjen »primanjkljaj« pri družinah in otrocih deluje v smislu »individualizacije družbene neenakosti $\ll$. posrednik med SES in razvojem otroka se kaže materina izobrazba, materino branje otroku, materin način interakcije z otrokom, model navezanosti med materjo in otrokom). 


\section{Nejasnost v pojmu družbene skupine in družbene neenakosti}

Družbena stvarnost, zapiše Bourdieu (2003: str. 8I) je »celota nevidnih razmerij, ta pa vzpostavijo prostor položajev, ki so drug drugemu zunanji, ki se določajo drugi glede na druge glede na bližino, sosedstvo in glede na oddaljenost, a tudi glede na relativni položaj«. Obstajata torej družbena struktura in v njej (strukturna) neenakost - da bi mogli o tem razmerju neenakosti govoriti in ga empirično preverjati, moramo najprej objektivirati položaje družbenih skupin. Še drugače: družbene skupine ne obstajajo $\mathrm{v} \gg$ družbeni realnosti« (ibid.: str. 85), ampak jih je treba »narediti «, da bi lahko primerjali njihove raznolike položaje v kompleksni družbeni strukturi. Da bi mogli torej karkoli povedati o neenakosti, moramo »narediti« entitete, med katerimi neenakost »obstaja« in je delujoča/učinkujoča. A to delo konstrukcije skupin ima nepredvidene učinke: najprej, med avtorji se pojavljajo velike razlike v tem, kako se »skupinjenja « lotijo - odvisno od disciplinarnega zaledja (sociologi vztrajajo pri »družbenih razredih«, discipline, ki so bližje naravoslovju, pa preferirajo »dohodkovne percentile populacije $\ll$ ali $\gg$ socialno-ekonomski indeks $\ll$ ) in zgodovinskega obdobja (delavski-kapitalistični razred je dihotomija, ki jo je najti skoraj izključno pri avtorjih v 20. stoletju; v sodobnosti so vse pogostejše tendenciozne formulacije tipa »prikrajšani $\ll$ in $\gg$ privilegirani $\ll$ sloji, »dominante $\ll$ in

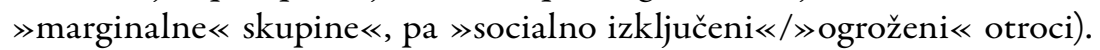
Razlike so osupljive že v številu skupin, ki jih v raziskavah primerjajo: od dveh (delavski in srednji razred), treh (višji, srednji in nižji razred), štirih (profesionalni, srednji, delavski in podrazred) do desetih različnih skupin (glede na dohodkovno skupino staršev). Poleg tega nikakor ne soglašajo o tem, katere lastnosti skupin so določujoče za njihovo uvrstitev v skupine/ razrede (glej tudi Klun, 2019). Če naštejemo le nekatere:

I) dohodki družine (bruto dohodek očeta/matere, staršev, količina ekonomskega kapitala v lastni družine),

2) zaposlitveni status enega ali obeh staršev (Marjanovič Umek in Fekonja, 2019),

3) socialnoekonomski indeks (na primer SES Index of Multiple Deprivation v Letts et al., 2013),

4) izobrazbena stopnja enega ali obeh staršev (kadar so uporabljeni podatki enega od staršev, gre prevladujoče za izobrazbo/zaposlitev matere) (Bornstein in Haynes, 1998; Fekonja et al., 2005; Hoff, 2003; Letts et al., 2013; Marjanovič Umek in Fekonja, 2019),

5) nastanitveni pogoji družine (na primer lastniško stanovanje/najemniško stanovanje/neprimerna nastanitev/brezdomstvo) (Schoon et al., 2010), 
6) življenje v bogati/revni soseski (Fernald, Marchman in Weisleder, 2013; Hart in Risley, 1995),

7) subvencionirana prehrana otroka,

8) vključenost v program za prikrajšane otroke (Hart in Risley, 1995).

Drugi nepredvideni učinek konstruiranja skupin pa je, da skupine - ko so enkrat »izdelane«, lahko prikrivajo realnost razmerij položajev v družbeni strukturi (Bourdieu, 2003). Bralec torej ne doume več relativnih objektivnih razmerij, iz katerih skupine izhajajo, ampak jih zvede na »interakcije, v katerih se pokažejo« (ibid.). Tako na primer višje/ nižje družbene skupine ne razbira kot analitične kategorije (ki razodevajo strukturno neenakost med položaji), ampak kot opisno kategorijo - kot opis življenjskega sloga, navad, jezikovnih stilov. To se zelo jasno pokaže, ko avtorji iščejo razlagalni mehanizem za povezanost med družbeno pripadnostjo in govorno-jezikovnim razvojem. Torej: korelacija med SES družine in razvojem govora otroka je potrjena. A kako pojasniti to korelacijo? Avtorji se obrnejo $\mathrm{k}$ opisnim dejavnikom primarnega okolja, ki delujejo kot mediatorji med položajem družine in razvojem otroka. Tudi pri tem med avtorji ni enotnosti, opredelijo povsem različne dejavnike, ki »vplivajo $\ll$ na govor in jezik otrok:

I) skupno branje staršev in otrok (Marjanovič Umek, Fekonja Peklaj in Sočan, 2017; Marjanovič Umek in Fekonja, 2019),

2) vključenost v predšolsko vzgojo (Letts et al., 2013),

3) število knjig v družini (uporablja se tudi kot kazalnik SES - glej zgornji stolpec; in kot »posrednik med SES in razvojem« Marjanovič Umek in Fekonja, 2019),

4) osredotočenost na otrokov govor, usmerjena pozornost na otroka, odgovarjanje na otrokova vprašanja, odzivnost na otrokove zgodnje vokalizacije (DeBlauw et al., 1978; Farran in Haskins, 1980),

5) kvantiteta govora, ki ga starši namenijo otroku (Hart in Risely, 1995; Hoff, 2003; Schwartz in Terrel, 1983),

6) kvaliteta govora, ki ga starši namenijo otroku (Hoff, 2003),

7) permisiven/avtoritaren/avtoritativen način vzgoje (Bernstein, 2003b; Hashima in Amato, 1996),

8) količina negativnih/pozitivnih pouratnih informacij, ki jih otrok dobi o svojem obnašanju (Hart in Risley, 1995),

9) število pogovornih obratov (izmenjave govorca $v$ interakciji med starši in otroki) (Gilkerson et al., 2017; Romeo et al., 2018a in 2018b; Petersen in Spencer, 2012), 
Io) prepričanja in znanje staršev o načinih vzgoje otrok - pripisovanje pomembnosti spodbujanju govora, gibalnih aktivnosti, simbolne igre, poznavanje razvojnih stopenj (DeBaryshe, Binder in Buell, 2000),

II) interakcijski stil in navezanost v družini-toplina, sprejemanje otroka itd. (Murray in Hornbaker, 1997).

Orisana raznolikost ni povezana $\mathrm{z}$ nedoslednostjo avtorjev, ampak izhaja iz narave predmeta - iz kontingentnosti »izdelave« družbenih skupin in primerjanja njihovih atributov. Sploh pa, kadar se preverja dispozicije otrok, ki sami po sebi ne sodijo v specifično skupino, ampak jo »pridobijo« po starših. Heinrich (2013) predlaga dvojno razumevanje družbenih razredov/skupin. Prvo je razumevanje razreda kot strukturne kategorije, drugo kot zgodovinske kategorije. V strukturnem smislu gre za relativni položaj, ki ga posameznik zaseda v družbenem produkcijskem procesu. Strukturnega položaja ne določa ta ali ona značilnost posameznika ali družine - na primer višina dohodka, izobrazbe, kulturni okus, ampak velja razred razumeti kot družbeni odnos. Družina torej zaseda mesto glede na vse ostale družine v družbeni delitvi dela. V zgodovinskem smislu pa gre za partikularno »pojavnost « razreda, ki jo je mogoče opisati in momentalno »uloviti« za namene raziskovanja - gre za način, na katerega pripadniki družbenih skupin obstajajo v določenem zgodovinskem, geografskem, socialnem in kulturnem kontekstu. V tem smislu je »družbeno skupino « mogoče opisati in jo primerjati z ostalimi v danem kontekstu. Ključno pa je, da strukturnih razredov ni mogoče enačiti z vsakokratnimi manifestacijami njihovih lastnosti. Kot zapiše Heinrich (ibid.: str. 212):

H kapitalistu ne sodita nujno cigara in voznik, prav tako proletarcev ne moremo reducirati na industrijske delavce, ki živijo v delavski soseski. Razkroj takšnih stereotipov ni dokaz o koncu razredov, temveč zgolj o spremembi njihove zgodovinske podobe.

Če zadevo približamo temi članka: k skupini $\mathrm{z} \gg$ nizkim $S E S \ll$ ne sodi nujno majhno število knjig in didaktičnih igrač, malo izrečenih besed skrbnika in avtoritarna vzgoja. K skupini $\mathrm{z}$ »visokim $\mathrm{SES} \ll$ ne sodi nujno obiskovanje muzejev in knjižnic, zgodnje opismenjevanje otrok in ljubezen do stročnic. Še tako »naturalizirani« kazalci umeščenosti v določen razred (na primer dohodek, izobrazba staršev), pa tudi bolj očitno arbitrarni (kulturni okus, omika, način komunikacije) - niso nespremenljivi del pripadnosti družbenemu razredu. Skozi zgodovinska okolja se življenjske okoliščine spreminjajo, kar pa ne ovrže obstoja razredne družbe in strukturne neenakosti. Ta distinkcija med strukturnim in zgodovinskim pojmovanjem družbenih skupin je ključnega pomena za razumevanje 
pomanjkljivosti raziskav. Avtorji za namene raziskav »napravijo« družbene skupine, ki jih med seboj primerjajo - a o družbenih skupinah skoraj brez izjeme pišejo v zgodovinskem, ne v strukturnem smislu. Rezultati raziskav pokažejo, da so med otroci prisotne razlike v razvoju in kogniciji. A kljub temu, da so razlike predstavljene preko zgodovinskih kazalcev družbene pripadnosti, izvirajo iz strukturnih značilnosti razredno deljene družbe. Diskurzivno neenakost je tako mogoče razumeti zgolj v funkciji strukturne neenakosti. Privilegirane in prikrajšane skupine so $\mathrm{v}$ neenakem položaju - semiotično in semantično »globino «, kompleksno sintakso, gostobesednost, leksikalno bogatost lahko razumemo kot »del privilegijev« višjih razredov.

\section{Nejasna vloga posrednikov}

Druga težava predstavljenih raziskav je nejasna vloga posrednikov med družbeno pripadnostjo in razvojnimi izidi otrok. Vprašanje, kot smo pokazali, je: Kaj stoji med »razredom《 in »razvojem《? Kot samoumeven vmesnik se kažejo značilnosti družinskega okolja. Te sodijo v opisni, zgodovinski »opus« pripadnosti razredu. Nekatere raziskave posrednike iščejo v številu knjig, skupnem branju, številu besed v okolju, drugi kar eksplicitno deklarirajo, da v razmerju »razred-razvoj《 mediira »kakovost družinskega okolja $\ll^{13}$ (npr. Farrant in Zubrick, 20II) - seveda s postavko, da višji SES pomeni večjo kakovost. To tezo težko podpremo - >posredovanost « med obojim je namreč izredno dvoumen pojav, ki vsekakor zahteva nadaljnjo razlago. $\mathrm{V}$ tem opažanju nikakor nismo sami - ne le kritiki, temveč tudi sami avtorji so opazili to pomanjkljivost svoje metode. Fernald, Marchmann in Weisleder (2013: str. 234) so tako zapisali, da se »večina raziskav ukvarja s površinskimi manifestacijami razlik - le malo pa se posvečajo razumevanju vzrokov in posledic variabilnosti.«

Velja dvoje: večina avtorjev se osredotoči na površinske značilnosti »razredne pripadnosti« (v zgodovinskem smislu), na drugi strani pa tudi na površinske značilnosti jezika staršev in otrok - raziskujejo leksiko (število besed v okolju in obseg besednega zaklada otrok) in sintakso (kompleksnost skladnje pri otroku), nekateri tudi slovnično pravilnost (na primer število napak v govoru), mnogo redkeje pa semantiko (abstraktni/konkretni pomeni, implicirani/eksplicirani pomeni; delež dekontekstualiziranega diskurza itd.). Nove tehnologije zbiranja in analize podatkov - na primer program LENA - ta trend še utrjujejo. Kljub nedvomni uporabnosti avtomatizirane analize jezikovnega okolja obstajajo omejitve - na slabosti opozarjajo tudi razvijalci sistema sami (Gilkerson et al., 20I7). Prvič,

I3 Pri tem je višjerazredno okolje kakovostno, nižjerazredno pa ne. 
v podatkih, ki jih pridobiva sistem LENA, ni $\gg$ nobenih informacij o pomenu besed, ki jih odrasli izrekajo otroku ali v bližini otroka « (ibid.: str. 262). Ta problem odstavljene ( $\mathrm{v}$ raziskavah spregledane) pomenske in kontekstualne ravni jezika, ki se mogoče zdi na prvi pogled banalen, je srž problematike »empirizacije《 razmerja med razredom in razvojem.

$\mathrm{Na}$ tem mestu so sistemski lingvisti in Bernstein (s podporo intelektualne dediščine Vigotskega, 1986) predstavili izredno prodoren uvid, ki prevprašuje vsa zbrana spoznanja empirističnih modelov: Nista sintaksa in leksika tisti, ki ustvarjata pomen, ampak je pomen tisti, ki »izbira《leksiko in sintakso. Tudi v otrokovem razvoju se semantična raven in zunanja (izmerljiva) raven govora razvijata v nasprotnih smereh, zato merjenje pojavnosti govora in jezika (besede, skladnja, slovnica) ni zadovoljivo merilo pri interpretaciji tega, kako otrok iz okolja privzema jezik. Kot zapiše Vigotski (ibid.), gre pri pomenski in zunanji (zvočni) ravni diskurza za $\gg$ različne razvojne zakonitosti gibanja«:

Če zaobjamemo začetno in končno stopnjo v razvoju semantične in fazične (zunanje) ravni govora, se torej lahko prepričamo, da razvoj na različnih ravneh poteka v nasprotnih smeri. Smiselna raven se razvija od celote k posameznemu delu (torej od stavka do besede), zunanja plat govora pa od dela k celoti (torej od besede do stavka). Že omenjeno dejstvo zadošča, da se lahko prepričamo o nujnosti razlikovanja med smiselno in zvenečo besedo, saj se gibanja na obeh ravneh ne prekrivajo in ne oblikujejo enotne skupne linije, temveč so si lahko /.../ tudi popolnoma nasprotna (1986: str. 218-219).

Zaradi tega je Bernstein (2003d) v svojem poznejšem delu, v sodelovanju s Hallidayem (1978 in 1995) in Hasan (1995), ostro zavrnil raziskave (vključno s svojimi), ki preučujejo leksiko govorjenega jezika in menijo, da so »našle« diskurzivni odtis družbene neenakosti. Oziroma še bolj pomembno: avtorje, ki zaključijo, da so »odkrili mehanizem « (Spencer in Peterson, 2012), ki posreduje med »razredom « in »razvojem«. Diskurzivno dedovanje družbenih položajev ti avtorji (vsi, ki smo jih našteli, pa tudi zgodnji Bernstein, 2003a) konstruirajo takole:

Družbena struktura neenakost $\rightarrow$ družinsko okolje $\rightarrow$ leksika, gramatika, sintaksa $\rightarrow$ semantika (pomeni, ki jih je mogoče izraziti) $\rightarrow$ kognicija (pomeni, ki jih je mogoče misliti)

Ugotovijo lahko, da deprivilegirani otroci in odrasli govorijo manj in imajo manjši besedni zaklad. Preko leksikalnih značilnosti družine naj bi otroci dedovali ostale jezikovne in kognitivne atribute. Slabša leksika 
torej dozdevno povzroča slabšo sintakso, bolj okrnjeno semantiko in nazadnje počasnejši kognitivni razvoj, celo drugačno razvijanje možganov. A ta kavzalnost ostaja nedokazana. Je semantika res »okrnjena《 na račun omejenega besednjaka in netočne sintakse nižjerazrednih otrok? Je njihov razvoj res počasnejši zato, ker starši rečejo manj besed? Ali je morda verigo konsekvenc misliti drugače? Pozni Bernstein (2003c in 2003d) se je z odločnostjo odvrnil od svojih začetnih hipotez. $V$ teku več desetletnega raziskovanja in konceptualnega izčiščevanja je s sodelavci (Hasan, 1995, 200I; Halliday, 1987, 1995) ugotovil, da je konsekvenca obratnaod te, ki jo avtorji predpostavljajo (in posledično tudi $\gg$ najdejo). $S$ tem so navedeni avtorji (ibid.) postavili empirične in teoretske temelje, ki preobračajo konsekvenco diskurzivnega dedovanja družbenih položajev:

Družbena struktura $\rightarrow$ semantika (pomeni, ki so posameznikom $\gg$ dostopni « - ki jih je mogoče izraziti in misliti) $\rightarrow$ leksika, sintaksa, gramatika

Razlike (po tem teoretsko utemeljenem razumevanju) med družbenimi skupinami sicer obstajajo - a te so le na površini »jezikovne « (Halliday, 2003b): v resnici jih je zmotno obravnavati kot preproste razlike $\mathrm{v}$ besednjaku ali rabi. Kajti $\mathrm{v}$ resnici te manifestacije (opazne razlike, ki jih raziskovalci prizadevno merijo) izvirajo iz raznolikega dostopa do pomenov. Še drugače - razlika je najprej sociosemantična, šele nato pa postane razlika $v$ besednjaku, skladnji in slovnici. Obe shemi razmerja poenostavljata, saj nikdar ne gre za »preprosto enosmerno kavzalno verigo « (Atkinson, 1985: str. 75), ampak za odnose relativne vzajemnosti. Vendar pa sta obe shemi dovolj točni, da pokažeta ključno različnost med obema načinoma razumevanja »posredovanosti $\ll$. $\mathrm{V}$ prvem primeru gre za to, da zgodovinsko pojmovani družbeni položaji (površinski kazalniki) vodijo $\mathrm{v}$ neenak besednjak, skladnjo in preko teh $\mathrm{v}$ neenako možnost ustvarjati kompleksne in abstraktne pomene. $\mathrm{V}$ drugem primeru pa gre za to, da stratificirana družbena struktura omogoča privilegiran dostop do semantičnih virov privilegiranim skupinam oziroma vpliva na neenako distribuiran dostop do (abstraktnih, dekontekstualiziranih) pomenov, šele preko tega pa vpliva na besednjak in skladnjo, ki ju je moč »izmeriti pri družinah in otrocih «. Bernstein (2003a) je poudaril, da je po desetletjih raziskovanja prepričan, da vsakršna opažena neenakost ne izhaja iz jezikovnih značilnosti, ampak iz semantičnih značilnosti diskurza.

Jezikovni kodi so povsem pogojeni z »družbenimi razmerji, v katera so vpeti ljudje, « (2003d: str. 82) in selektivno vplivajo na njihov dostop do diskurzivnih virov. Posebnosti jezika ne izhajajo iz psiholoških značilnosti posameznika (sposobnosti, inteligence) niti iz značilnosti okolja, 
ampak iz »specializiranega socialnega položaja, ki je v funkciji družbene strukture in sistema socialne stratifikacije $\ll$ (2003d: str. IO2).

\section{Povezanost ali povzročenost?}

Najbolj neugoden izid raziskovalne vneme na področju je, da številčnost podatkov ustvarja vtis konciznosti in koherentnosti, četudi je teoretski aparat (v katerega se podatkovje nujno vpenja) oslabljen in dopušča rokohitrske zaključke (Dudley-Marling; Lucas, 2009). Ena najbolj mikavnih zmot izhaja iz dejstva, da je »reproduktivne sile《sicer mogoče opazovati in izmeriti $v$ zgodovinskem smislu, delujejo pa v strukturnem smislu razredne razdeljenosti. Kar se kaže kot simptom, se prebira kot izvor. Kar se kaže kot »primanjkljaj«v govoru in jeziku deprivilegiranih otrok, je sicer mogoče (z izredno natančnostjo) korelirati z aspekti primarnega okolja družin težava nastane, ko se korelacije razume kot kavzalnost. Če poenostavimo: mogoče je najti povezanost med številom knjig v gospodinjstvu in hitrostjo govorno-jezikovnega razvoja otrok. A če vsaki deprivilegirani družini podarimo omaro knjig ali starše poučimo o pomembnosti branja, s tem ne bomo dosegli (dolgoročnih) pospeškov v otrokovem razvoju. Vzročnost, kakršno je slutiti, v realnosti ne vzdrži. Neenakosti izhajajo iz strukturnih značilnosti neenakih položajev družin in otrok, ne pa iz partikularnih manifestacij neenakosti (kot so število knjig, ure skupnega branja, število besed). Tako so načrti, ki poskušajo spoznanja na tak - »zdravorazumski način « - aplicirati v prakso, osnovani na napačni postavki (Burman, 2008; Gillies 2007).

Zagata se pojavi na dveh točkah:

I) ko se strukturne neenakosti enači z vsakokratnimi manifestacijami teh neenakosti in

2) ko se korelacijo med manifestirano razrednostjo in razvojnimi/učnimi izidi otrok prebira kot »kavzalnost « - ko se povezanosti med spremenljivkami (na primer med SES in obsegom besednjaka) ne razume zgolj kot povezanosti, ampak se razmerju med enim in drugim pripisuje odnos »povzročenosti«. Pri čemer se zazdi, da specifični »atributi razrednega okolja« povzročajo (določljive) specifične učinke pri otroku.

Kot opomni Bourdieu:

Interakcije, ki prinašajo empirističnim dispozicijam takojšnje zadovoljstvo - lahko jih opazujemo, posnamemo na film, registriramo, skratka, se jih dotaknemo s prstom - prikrivajo strukture, ki se tukaj realizirajo. To je eden izmed primerov, ko vidno, tisto, kar je neposredno dano, prikriva 
nevidno, ki ga določa. Tako pozabljamo, da resnica interakcije ni nikoli vsa v interakciji, kakršna se ponuja opazovanju (2003: str. 82).

Opisane (zmotne) interpretacije imajo nenadejan učinek: individualizacijo družbene neenakosti. Ta se kaže v trojem: v prelaganju odgovornosti za socialno reprodukcijo na starše ( $\mathrm{ki} \gg$ organizirajo « premalo kakovostno domače okolje); patologizaciji otrok (iskanje primanjkljaja v otroku samem, ki se kaže $\mathrm{v}$ domnevni abnormalnosti njegovega razvoja) in $\mathrm{v}$ snovanju intervencij, ki poskušajo s pedagoškimi sredstvi »kompenzirati« družbeno neenakost (pri otroku ali družini). Vse tri učinke povzame Burman (1994, v Gillies, 2007), ko razvojno psihologijo in sorodne discipline označi za »politično sredstvo, ki je uporabljeno za regulacijo (revnih) otrok in njihovih staršev«.

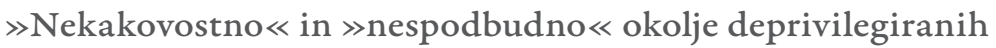 družin}

Kritiki avtorjev Hart in Risley (ter njune teze o jezikovni »vrzeli«) zapišejo, da je najbolj problematična njuna »pripravljenost, da podajata brezkompromisne trditve o kakovosti govora, ki ga starši namenjajo otrokom« (Dudley-Marling in Lucas, 2009: str. 368). Na nekaterih mestih zatrdita, da je količina besed v višjerazrednih družinah povezana $\mathrm{z}$ njihovo kulturo, »skrbjo za omiko« (Hart in Risley, 1995: str. 58) ter z nagnjenostjo $\mathrm{k}$ »analitičnemu reševanju problemov« (ibid.: str. 133). Podobne tendence je opaziti tudi pri slovenskih avtorjih. Gaber (2010) v spremni besedi k slovenskemu prevodu dela Vigotskega zapiše:

Ob privzetju pomena družbene akumulacije vednosti v kulturi pa v ospredje stopi tudi pomen kakovosti otrokovega kulturnega okolja za razvoj mišljenja. Okolja pri tem odigrajo vlogo spodbujevalcev - bolj ali manj uspešnih - razvoja predvsem otrokovih višjih mentalnih funkcij. /.../ Od tu je mogoč korak v razmislek o razliki med vplivom matere srednjega razreda in matere nižjega delavskega razreda (ibid.: str. 267).

Tudi Camović (2019) se v članku v reviji Sodobna pedagogika ozre k staršem. Sklene, da deprivilegiranost sicer vpliva na razvojne poteke otrok, vendar je - sodeč po raziskavah - to moč preprečiti z preprostimi »spremembami« v življenjskem slogu družin:

Čeprav nizek socialno-ekonomski status in nizka dosežena izobrazba staršev predstavljata dejavnike tveganja za otrokovo uspešnost, je mogoče te negativne dejavnike preiti z starševskim prizadevanjem in aktivno vključenostjo v vzgojo otroka. Vsak otrok si zasluži starša, ki bo omogočal podporno in odgovorno vzgojo (ibid.: str. 174). 
Takih interpretacij ne manjka - ne le pri raziskavah govora in jezika deprivilegiranih otrok, ampak prevladujejo tudi pri avtorjih, ki se ukvarjajo z drugimi aspekti razvoja. Način, na katerega razumejo povezanost (dozdevno kavzalnost) med »razredom « in »razvojem «, sijajno povzame Heckman, ko zapiše (200I: str. 83): »Pravo merilo otroške revščine je kakovost starševstva, ki ga je otrok deležen, ne le količina denarja, ki je na voljo v gospodinjstvu.« Le korak je od te postavke do stališča, da družbena neenakost »izhaja iz razlik v starševstvu. Po tem razumevanju, zapiše Gillies (2005), je kakovostna vzgoja edina stvar, ki je potrebna, da se otrokom zagotovi enakost možnosti. In takoj za tem pride bralcem na misel, da so »revni starši tisti, ki so odgovorni, da na svoje potomce prenesejo znanja in veščine, ki so potrebna, da dosežemo družbeno pravičnost« (Gilles, 2007). Ta »uvid« nenamerno potencirajo sodobne nevroznanstvene raziskave, ki diseminirajo idejo, da je družbena neenakost preko primarne vzgoje vpisana v biologijo posameznika. Kakovostna oziroma nekakovostna vzgoja staršev se »pozna« v dobrem/slabem razvoju otrokovih možganov. Tako avtorji (Romeo et al., 2or8b) zatrdijo:

Spoznanja nakazujejo, da bi povečanje govornih obratov lahko pospešilo strukturni razvoj možganov in jezikovne zmožnosti, ki jih razvoj možganov omogoča pri otrocih ne glede na njihovo družbeno ozadje (Romeo et al., 20I8b: str. 7876).

O razliki med korelacijo in kavzalnostjo ne bomo več razpravljali. Avtorji raziskav sicer kontrolirajo za »socialno-ekonomski status« družin ${ }^{14}$. A predhodno smo pokazali, kako izmuzljive in problematične so interpretacije, ki poenostavljajo proces konstrukcije »razredov« ter razmerja med $\gg$ razredi $\ll / \ll$ družbenimi skupinami $\ll$, med $\gg$ razredom $\ll$ in »razvojem« (tudi če gre za »razvoj možganov«). Tovrstne trditve vedno dajejo zagon vrsti zdravorazumskih namigov, kaj vse bi lahko revni starši (predvsem matere) napravili, da bi presegli učinke svojega negativnega družbenega položaja in »omogočili《 socialno mobilnost svojib otrok (Bunting, 2004, v Gillies, 2007; Ramirez, Lytle, Kuhl, 2020). Wheeler in Connor (2009) napravita kar seznam spodbudnih aktivnosti, ki »razvijajo otrokove možgane« (»stretch the child's brain«, v Camović, 2019: str. 174): »branje z otrokom in branje otroku, obiski, priložnost za igro s prijatelji, igra s črkami in številkami, obiski knjižnice, rimano prepevanje, risanje, slikanje, ...« Vsega tega ni težko doseči - četudi so starši deprivilegirani. Iz tega izvira domneva, da bi za udejanjanje družbene enakosti potrebovali le

I4 In ob kontroliranem SES pokažejo na povezanost med številom govornih obratov in izmerjeno aktivnostjo v otrokovih možganih. 
»šolo《 za revne starše (predvsem pa matere, Gillies, 2007), da bi jim naučili »bolje«vzgajati otroke. Kot zapiše Camović (2019: str. I89):

Rezultati so uporabni pri snovanju programov za starše. /.../ Programi za starše bi staršem lahko pomagali, da izboljšajo svojo vzgojo in kakovost domačega učnega okolja, da izboljšajo razvoj in učenje svojih otrok. Razvojna vrzel, ki se zelo zgodaj pojavi med otroci z različnimi socialno-ekonomskimi ozadji, bi lahko bila zmanjšana, če bi starše opolnomočili in opogumili, da se z otroki ukvarjajo na načine, ki prispevajo k zgodnjemu razvoju in učenju. /... / Starše (posebno starše z dejavniki tveganja) je potrebno seznaniti, da je to, kar počnejo z otroci na vsakdanji bazi, pomembno determinira otrokovo uspešnost ...

Poantiran pomislek v zvezi s osredotočenostjo na »kakovost $\ll$ starševstva napravi Atkinson (1985): poudari, da na družbeno neenakost ne moremo pogledati kot na preprosto razporeditev »dobrega « in »slabega « starševstva v smislu boljših/slabših vsakdanjih praks. Družba ni mreža enakopravnih dispozicij, v kateri imajo vsi enak dostop do ekonomskih, socialnih in diskurzivnih virov - le da nekateri ta dostop »izkoristijo «, drugi pa ne. Položaj v družbeni strukturi ni stvar izbire posameznih staršev (npr. izbire pravih komunikacijskih praks, »pravega k kulturnega okusa):

O različni distribuciji kodov ne moremo misliti kot o posledici, bolj ali manj naključni distribuciji družbenorazredne kulture ali pa kot o kulturnem $\gg$ zaostanku $\ll$ na strani delavskega razreda, v smislu regulacije lastnih otrok, ampak je (različna distribucija kodov) neposredno povezana z socialno distribucijo znanja in moči, glede na družbeno delitev dela (Atkinson, ibid.: str. 75).

\section{Sklep: Diskurzivna neenakost in poskus strukturnega} razumevanja izmerjenega $\gg$ primanjkljaja $\ll$

Zaključujemo z mislijo, da bi bilo smiselno »resociologizirati« problematike, ki so prvenstveno družbene, šele konsekventno pa razvojne, psihološke, lingvistične in edukacijske. Soglašamo z Lukom (2006), ki poudarja, da je treba jezik prikrajšanega subjekta približati sociološki in ekonomski analizi njegove strukturne pozicije - kognitivni in idejni potenciali jezika so namreč mediirani s strani ekonomskih in družbenih razmer oziroma, bolj natančno, s strani relativnega (subjektovega) položaja v družbeni strukturi. Ključna točka »resociologizacije« je kritično ovrednotenje avtorjev, ki v zadnjih desetletjih merijo, korelirajo in obenem - proizvajajo - pojem primanjkljaja deprivilegiranih družin in otrok. Obravnavani 
avtorji družbeno neenakost razumejo zgodovinsko in realistično, ne pa strukturno - otrokov »pomanjkljiv razvoj« razumejo v navezavi na dozdevno »nekakovostno《 kulturo, nespodbudno okolje in premalo gostobesedne starše v nižjerazrednih družinah. Rešitev pa v intervenciji v družinske prakse, komunikacije, kulturo ter kompenzacijo za otrokov »neugodni razvojni potek «. Omejitve raziskav (metodološke, vsebinske) in interpretacij koncizno povzame Burman (2008) v knjigi Deconstructing developmental psychology:

Metodološke in interpretacijske omejitve raziskovanja vzbujajo idejo o govorno-jezikovnem razvoju, ki je poenostavljena in neobčutljiva za analiziranje specifičnih značilnosti jezikovnega okolja, ki igrajo vlogo v razvoju govora. Ne le, da ti ekscesi onemogočajo razumevanje tega, kako se govor, ki je namenjen otroku, povezuje z usvajanjem in razvojem jezika, ampak raziskovanje vzpostavlja neupravičen negativen stereotip o skrbnikih, ki so ritualno določeni kot pomanjkljivi v svojih zmožnostih podpirati razvoj jezika (ibid.: str. 203).

Primanjkljaj je realen in izmerljiv (vseh rezultatov ni mogoče ovreči le zato, ker progresivnemu znanstveniku povzročajo nelagodje). A vendar: ni realen zato, ker je izmerljiv/opazen, temveč je realen, ker je strukturen. Na tej točki se pogosto zameša vzročnost in posledičnost. Realen primanjkljaj, ki je pogojen z družbeno-razredno strukturo, je mogoče pokazati šele na ravni individualne pojavnosti. Še drugače: primanjkljaj je strukturen in izvira iz tega, da so določeni razredi vladajoči, drugi pa podrejeni. A empirično je mogoče pokazati primanjkljaj le kot manko na ravni besednjaka, govornega bogastva, sintakse ali kot »razvojni zaostanek« deprivilegiranih otrok. Meritve pokažejo na simptom, ne na izvor deprivilegiranosti. A kljub temu zaradi napačne interpretacije pogosto upravičujejo »kompenzacijske« programe, ki targetirajo deprivilegirane otroke in starše ter poskušajo $\mathrm{z}$ »jezikovno « in »kognitivno « podporo razrešiti problem razredne neenakosti. A kot opozori Mey (1985):

Jezikovna neenakost je družbeni problem, ki ne more biti rešen z jezikovnimi sredstvi. /.../ Naj poudarim, da imajo lingvistični modeli, ne glede na to, kako nedolžni in teoretsko izčiščeni se zdijo, vedno določene ekonomske, socialne in politične predpostavke, pa tudi posledice. Jezikovne in ostale neenakosti ne prenehajo obstajati samo zato, ker so socialnoekonomski pogoji njihovega obstoja pometeni pod lingvistično preprogo. Tančica lingvistične manipulacije, ki se pripenja na zavest deprivilegiranih, se lahko skriva, ne more pa ukiniti obstoječega stanja družbene neenakosti (ibid.: str. 26). 
Če poenostavimo: $v$ govoru in jeziku deprivilegiranih skupin obstaja relativni primanjkljaj, ki je $\mathrm{v}$ funkciji družbene neenakosti - vladajoče družbene skupin si lastijo privilegirajoče diskurzivne vire, tiste, ki so razlašcene, pa so razlaščene na področju ekonomskih, socialnih, kulturnih, pa tudi diskurzivnih virov. Pojmovanje »primanjkljaja « (za katerega smo rekli, da je realen, ker je strukturen) je pravzaprav nekoliko netočno: pri deprivilegiranih skupinah ne gre za uporabo jezika, ki bi bil kvalitativno »enak« kot jezik privilegiranih skupin, le osiromašen/deficitaren (manj besed, manj pravilna slovnica, manj spretna skladnja). Diskurzivna razlika med družbenimi skupinami ni razmerje manj (nižji razred) - več (višji razred), temveč je med »govorno-jezikovnimi dispozicijami« obojih kompleksno razmerje družbene neenakosti. Jezik deprivilegiranih družbenih skupin je torej relativno »deficitaren « ravno zato, ker je jezik podrejanja. Vsak program in izobraževalna politika, ki predpostavlja, da bi bilo mogoče neenakost kompenzirati z večjim »jezikovnim vnosom « in boljšimi pedagoškimi prijemi (naj otroci slišijo več besed, se naučijo pravilne skladnje, naj se igrajo $\mathrm{z}$ didaktičnimi igračami), spregleda temeljne mehanizme reprodukcije družbene neenakosti. $V$ resnici gre pri avtorjih in snovalcih intervencij za prenaglo indukcijo (partikularnih spoznanj) in zmotno interpretacijo odnosa med izvorom in manifestacijo. Spregledan je izvor neenakosti in problematika je nagovorjena šele pri manifestaciji (z razvojno-psihološkimi, nevrobiološkimi, logopedskimi raziskavami). To zmoto je sicer anticipiral že Bernstein (2003d: str. 82):

Nujno je imeti v mislih distinkcijo med izvorom, kjer »nastajajo govorne
oblike« - to so družbena razmerja - in opisom kazalnikov govornih ob-
lik. Kar se je zgodilo v zadnjih desetletjih raziskovanja, je /.../ poskus, da
bi osnovali splošno in natančno formulacijo načel, ki generirajo različne
jezikovne oblike, torej družbeno razrednih razmerij, »delujočih« preko
jezika, in na drugi strani bolj sistematičen, splošen in natančen opis gov-
ornih oblik.

$\mathrm{V}$ zadnjih desetletjih je bilo narejenega veliko dela na drugem koncu problema - pri sistematičnem in natančnem opisu govornih oblik. Manifestacije merijo, korelirajo in razkrivajo empirične raziskave. Pri izvoru pa je nujno ubrati drugačno pot: najprej o njem govoriti sociološko, semantično, šele $v$ dodelan teoretski okvir pa je mogoče umestiti ( $v$ njem interpretirati) neenakosti $v$ leksiki, sintaksi, slovničnosti in nazadnje $v$ govorno-jezikovnem razvoju otrok. Če je ta veriga kavzalnosti na neki točki neupravičeno prekinjena ali celo obrnjena in je prednji del analize (sociološki in semantičen) amputiran, ostane malo možnosti, da bi bilo tisto, kar je ugotovljeno, celostno in utemeljeno. Obenem pedagoške, 
psihološke in zdravstvene »rešitve «, ki izhajajo iz take pol teorije, vodijo v neustrezne rešitve. Poleg splošne neučinkovitosti upravičujejo prenos odgovornosti na »nekompetentne revne starše « in s prstom pokažejo na dozdevno neprizadevnost pri razvojni stimulaciji otrok. Poleg tega »polovično « branje vodi v razumevanje govorno-jezikovnega zaostanka kot otroku inherentne patologije; tak vtis (nenamerno) utrjujejo nevroznanstvene raziskave, ki fokus še dodatno zanihajo v prid (biološke) pojavnosti primanjkljaja. Nazadnje socialnoekonomska podstat neenakosti postane (nepotrebna) formalnost na začetku člankov, deskriptivni zaznamek brez analitične moči. Brezpredmetno se zdi razkleniti problematiko in jo obravnavati zgolj v delu. Poleg tega dobrohotni - a nereflektirani - poskusi, da bi razkrili in posegli v mehanizem socialne reprodukcije, včasih delujejo kontraproduktivno in zaostrijo obstoječe neenakosti. Ta članek je korak h kritičnemu branju raziskav in poskus vnosa jasnosti v zgoščeno znanstveno področje.

\section{Literatura}

Atkinson, P. (1985) Language, structure and reproduction: An introduction to the sociology of Basil Bernstein. London: Meuthen.

Bernstein, B. (1958) Some sociological determinants of perception: an enquiry into sub-cultural differences. British Journal of Sociology 9 , str. I59-174.

Bernstein, B. (2003a) Class, codes and control, Volume I: Theoretical studies towards a sociology of language. York: Routledge, Taylor and Francis Group.

Bernstein, B. (2003b) Class, codes and control, Volume II: Applied studies towards a sociology of language. York: Routledge, Taylor and Francis Group.

Bernstein, B. (2003c) Class, codes and control, Volume III: Towards a theory of educational transmissions. York: Routledge, Taylor and Francis Group.

Bernstein, B. (2003d) Class, codes and control, Volume IV: The structuring of pedagogic discourse. London in New York: Routledge, Taylor and Francis Group.

Bornstein, M. H., in Haynes, M. O. (1998) Vocabulary competence in early childhood: measurement, latent construct and predictive validity. Child Development 69, str. 654-67 I.

Bourdieu, P. (2003) Sociologija kot politika. Ljubljana: Založba $/{ }^{*} c f$.

Burman, E. (2008) Deconstructing developmental psychology: Second edition. London in New York: Routledge. 
Dawe, H. C. (1942) A study of the effect of an educational programme upon language development. The Journal of Experimental Education II(2), str. 200-209.

DeBaryshe, B. D., Binder, J. C., in Buell, M. J. (2000) Mothers' implicit theories of early literacy instruction: Implications for children's reading and writing. Early Child Development and Care 160, str. 119-131.

DeBlauw, A., Dubber, C. van Roosmalen, G., in Snow, C. E. (1978) Sex and social class differences in early mother-infant interaction. V Garnica, O., in King, M. (ur.). Language, children, and society. New York: Pergamon Press.

Farran, D. C., in Haskins, R. (1980) Reciprocal influence in the social interactions of mothers and three-year-old children from different socioeconomic backgrounds. Child development 5I(3), str. 780-791.

Farrant, B., in Zubrick, S. (2012) Early vocabulary development: The importance of joint attention and parent-child book reading. First Language 32 , str. $343-364$.

Fekonja, U., Marjanovič Umek, L., in Kranjc, S. (2005) Otrokov govorni razvoj v povezavi z njegovim spolom in izobrazbo staršev. Psihološka obzorja I $4(\mathrm{I})$, str. 53-79.

Fernald, A., Marchman, V. A., in Weisleder, A. (2013) SES differences in language processing skill and vocabulary are evident at 18 months. Developmental Science 16 (2), str. 234-248.

Gaber, S. (2010) Vigotski, sociologija, učenje in poučevanje - skice. V Vigotski, L. (2010): Mišljenje in govor. Ljubljana: Pedagoška fakulteta.

Ganek, H. V., in Eriks-Brophy, A. (2017) A concise protocol for the validation of language environment analysis (LENA). Conversational turn counts in Vietnamese. Communication Disorders Quarterly 39, str. $37 \mathrm{I}-380$.

Gilkerson J., Richards J. A., Warren S. F., Montgomery J. K., Greenwood C. R., Kimbrough O. D., Hansen J. H., in Paul, T. D. (2017) Mapping the early language environment using all-day recordings and automated analysis. American Journal of Speech-Language Pathology 26(2), str. I-I8.

Gilkerson, J., in Richards, J. A. (2009) The power of talk: Impact of adult talk, conversational turns, and $T V$ during the critical o-4 years of child development. LENA Foundation Technical Report. Boulder: LENA Foundation.

Gillies, V. (2005) Raising the meritocracy: parenting and the individualization of social class. Sociology 39 (5), str. $835-852$. 
Gillies, V. (2007) Marginalized mothers: Exploring working-class experiences of parenting. London in New York: Routledge.

Gumprez, J., in Hymes, D. (ur.) (1964) The ethnography of communication. American Antopology Special Publication 66, str. I-34.

Halliday, M. A. K. (1978) Language as social semiotic: The social interpretation of language and meaning. London: Edward Arnold.

Halliday, M. A. K. (1995) Language and the theory of codes. V Sadovnik, A. (ur.). Knowledge and pedagogy: The sociology of Basil Bernstein. Westport: Ablex.

Hart, B., in Risley, T. R. (1995) Meaningful differences in the everyday experience of young American children. Baltimore, MD: Paul H. Brookes Publishing Company.

Hart, B., in Risley, T. R. (2003) The early catastrophe. The 30-million-word gap. American Educator 27(I), str. 4-9.

Hasan, R. (1995) On social conditions for semiotic mediation: the genesis of mind in society. V Sadovnik, A. R. (ur.). Knowledge and pedagogy: The sociology of Basil Bernstein. Norwood: $\mathrm{Nj}$ : Ablex.

Hashima, P.Y., in Amato, P. R. (1994) Poverty, social support, and parental behavior. Child Development 65, str. 394-403.

Heckman, J. (20II) The American family in black \& white. A post-racial strategy for improving skills to promote equality. Daedalus I 40, str. 70-89.

Heinrich, M. (2013) Kritika politične ekonomije. Ljubljana: Založba Sophia, zbirka Naprej.

Hirsh-Pasek, K., Adamson, L. B., Bakeman, R., Owen, M. T., Golinkoff, R. M., Pace, A., Yust, P. K., in Suma, K. (2015) The contribution of early communication quality to low-income children's language success. Psychological Science 26, str. 1071-1083.

Hoff, E. (2003) The specificity of environmental influence: Socioeconomic status affects early vocabulary development via maternal speech. Child Development 74, str. 1368-1878.

Jager, J. (2015) Odnos ravnateljev in strokounih delavcev vrtcev ter predstavnikov lokalnih skupnosti do izvajanja predšolskih programov za ogrožene otroke (doktorska disertacija). Koper: Pedagoška fakulteta Univerze na Primorskem.

Klun, L. (2019) Jezikovni kodi in neenakost v pedagoškem diskurzu: Problematika Basila Bernsteina (Magistrsko delo). Univerza v Ljubljani, Pedagoška fakulteta, Ljubljana. 
Lawton, D. (1968) Social class, language and education. V. Burkam, D. T. (ur.). Inequality at the starting gate: Social background differences in achievement as children begin school. Washington, DC: Economic Policy Institute.

Letts, C., Edwards, S., Sinka, I., Schefer, B., in Gibbons, W. (2013) Socioeconomic status and language acquisition: Children's performance on the new Reynell developmental language scales. International Journal of Language and Communication Disorders 48, str. I3I-I 43.

Luke, A. (2006) Class language. V K. Brown (ur.). Encyclopedia of Language and Linguistics. Elsevier Science.

Marjanovič Umek, L., Fekonja, U., Peklaj, C., in Sočan, G. (2017) Early vocabulary, parental education and the frequency of shared reading as predictors of toddler's vocabulary and grammar at age 2,7: a Slovenian longitudinal CDI study. Cambridge: Cambridge University Press.

Marjanovič Umek, L., in Fekonja, U. (2019) Zgodnji govorni razvoj: Varovalni dejavniki in dejavniki tveganja v družinskem okolju. Javno zdravje 02 , str. $\mathrm{I}-\mathrm{I} 3$.

Marjanovič Umek, L., in Fekonja Peklaj, U. (2OII) Lista naslovov in avtorjev otroških knjig: Priročnik. Ljubljana: Center za psihodiagnostična sredstva.

Marjanovič Umek, L., Fekonja, U., Peklaj, C., Sočan, G., in Komidar, L. (2011) Ocenjevanje sporazumevalnih zmožnosti dojenčkov in malčkov. Lista razvoja sporazumevalnih zmožnosti: Besede in geste in Lista razvoja sporazumevalnih zmožnosti: Besede in stavki. Ljubljana: Center za psihodiagnostična sredstva.

McCharty, D. M. (1930) The language development of the pre-school child. Oxford: University Minnesota Press.

Mladenović, A. (2016) Pomen intersekcionalnega pristopa pri obravnavi kompleksnih neenakosti. Šolsko polje 27, str. 95-II6.

Murray, A.D., in Hornbaker, A. V. (1997) Maternal directive and facilitative interaction styles: Associations with language and cognitive development of low risk and high-risk toddlers. Development \& Psychopathology 9 (3), str. 507-516.

Olson, D. R., in Bruner, J. S. (1996) Folk psychology and folk pedagogy. V Olson, D. R., in Torrance, N. (ur.). The handbook of education and human development: New Models of Learning, Teaching and Schooling. Wiley-Blackwell.

Petersen D. B., in Spencer T. D. (2012) The narrative language measures: Tools for language screening, progress monitoring, and intervention 
planning. Perspectives on Language and Learning Education 19, str. II9-I29.

Ramirez, N. F., Lytle, S. R., in Kuhl, P. K. (2020) Parent coaching increases conversational turns and advances infant language development. Proceedings of the National Academy of Sciences of the United States of America II7 (7), str. 3484-3491.

Rorty, R. (1967) The linguistic turn: Recent essays in philosophical method. Chicago: The University of Chicago Press.

Romeo, R. R., Leonard, J. A., Robinson, S. T., West, M. R., Mackey, A. P., Rowe, M. L., in Gabrieli, J. D. E. (2018a) Beyond the "30 million-word gap:” children's conversational exposure is associated with language-related brain function. Psychological Science 29, str. 700-710.

Romeo, R. R., Segaran, J., Leonard, J. A., Robinson, S. T., West, M. R., Mackey, A. P., Yendiki, A., Rowe, M. L., in Gabrieli, J. E. D. (2018b) Language exposure relates to structural neural connectivity in childhood. The Journal of Neuroscience 38 (36), str. 7870-7877.

Rowe, M. L. (2012) A longitudinal investigation of the role of quantity and quality of child-directed speech in vocabulary development. Child Development 83, str. 1762-1774.

Schoon, I., Parsons, S., Rush, R., in Law, J. (2010) Childhood language skills and adult literacy: A 29-year follow-up study. Pediatrics (Official Journal of the American Academy of Pediatrics) I25 (3), str. 459-466.

Schwartz, R. G., in Terrel, B. Y. (1983) The role of input frequency in lexical acquisition. Journal of Child Language Io (I), str. 57-64.

Vigotski, L. S. (2010) Mišljenje in govor. Ljubljana: Pedagoška fakulteta Univerze v Ljubljani.

Vygotsky, L. S. (1986) Thought and Language (Revised and edited by Alex Kozulin). Cambridge, Massachusetts, London: The MIT Press. 